\title{
Correspondence
}

http://dx.doi.org/10.11646/phytotaxa.172.3.11

\section{Type specimens of Tamarix (Tamaricaceae) described by Josef Franz Freyn in 1903}

\author{
JOSE LUIS VILLAR ${ }^{1 *}$, ANA JUAN ${ }^{1}, \mathrm{M}^{\mathrm{a}}$ ÁNGELES ALONSO ${ }^{1} \&$ MANUEL B. CRESPO ${ }^{1}$ \\ ${ }^{1}$ CIBIO (Instituto Universitario de la Biodiversidad), Universidad de Alicante, P.O. Box 99, ES-03080 Alicante, Spain, \\ e-mail: jose.villar@ua.es \\ *Author for correspondence
}

Five Tamarix taxa were described in Freyn's posthumous publication (Freyn 1903): Tamarix askabadensis Freyn (1903: 1059), Tamarix karakalensis Freyn (1903: 1060), T. karakalensis var. scoparia Freyn (1903: 1062), T. karakalensis var. verrucifera Freyn (1903: 1062), and T. karakalensis var. myriantha Freyn (1903: 1062). This publication comprised an enumeration of the plants collected by Paul Sintenis in "Tauria, 1900-1901" (in the Sintenis's voucher labels as "Iter transcaspico-persicum 1900-1901"), by Ove Paulsen in "regione caspica, transcaspica, praesertium in altiplanitie Pamir, 1898-1899", and by Victor Ferdinand Brotherus "in Turkestania, 1896". However, all Tamarix taxa treated in that work belong to those collected by Sintenis. It is important to point out that Sintenis was mostly a plant collector who sold his vouchers to many different herbaria: ANK, BHUPM, BREM, G, GH, HAC, JE, LD, PAL, PR, TUB, VT, W, WAG, and WU (acronyms according to Thiers 2014). However, his personal herbarium (ca. 80000 vouchers of 18000 species) was acquired by the Herbarium of the Botanical Museum of Lund (LD) in 1921-1922 (Patrik Frödén pers. comm.).

Sintenis's labels are printed, bearing the name of the new Tamarix species and varieties, together with the quotation "determ. J. Freyn". Accordingly, it can be assumed that Freyn personally examined and identified the Sintenis collections before the labels were printed and the vouchers distributed. In the protologue of each variety of $T$. karakalensis, Freyn (1903: 1062) referred clearly to the specimens kept at his personal herbarium, which is currently conserved at the Moravian Museum of Brno (BRNM), whereas no specific mention was made to T. karakalensis or T. askabadensis. Therefore, those vouchers kept at BRNM should have been considered as the holotypes for the three described varieties, though Baum (1966: 62) reported the holotypes of T. karakalensis var. scoparia and T. karakalensis var. myriantha at the herbarium of the Conservatoire et Jardin botaniques de la Ville de Genève (G). Surprisingly no specimen of T. askabadensis, T. karakalensis or any of its varieties is currently found in Freyn's herbarium at BRNM. It turns out that Freyn examined personally the Sintenis's 1900-1901 collections in 1902 (Karel Sutorý pers. comm.). But after Freyn's early dead in January 1903, it might be assumed that those examined vouchers were not sent to him, and they still remain at Sintenis's herbarium, which is currently conserved at LD. Some of those Tamarix specimens at LD were personally examined by Freyn, since there is one copy of each taxa that bears Freyn's handwriting, indicating even the precise day he examined them. Consequently, these vouchers would be considered as the best choice for typification of each of the Tamarix taxa [Art. 9.3(a) of the ICN, McNeill et al. 2012], and they have been given priority when possible.

According to the printed labels of the original collections of T. askabadensis, T. karakalensis and its three varieties, the authorship appears to be attributed to Freyn and Sintenis. It is probable that they agreed to publish the new taxa discovered amongst the Sintenis's 1900-1901 collections sharing the authorship. Nevertheless, Freyn (1903: 1059, $1060,1062)$ indicated the new taxa only as " $n . s p$. .", and " $n$. var.", hence the valid authorship belongs only to Freyn (Art. 46.8 of the ICN), and the shared authorship (Freyn et Sint.) remains only on the voucher labels ("in sched.").

Although type specimens for almost every Tamarix species, subspecies or varieties described until 1966 were included in Baum's monograph about this genus (Baum 1966), those Tamarix taxa described by J.F. Freyn were proven to need some clarification after studying the materials kept at some important herbaria (B, G, JE, LD, MO, P, $\mathrm{PR}, \mathrm{PRC}$, and $\mathrm{W}$ ). In the present contribution, the information of the labels is always given between inverted commas. The handwritten text has been transcribed to italics, and the typewritten text is maintained as standard font. Material from JE, LD, and WU has been studied from digital images. The " $a$ " and " $b$ " besides G herbarium numbers refer to a second and third sheet under the same herbarium number. 
Notes:-Freyn (1903: 1062) based the original description of T. karakalensis var. verrucifera on the Sintenis $646 a$ collection. Only two vouchers of this collection (B-100278715 and LD-1667358) have been found among all the studied materials. According to the existing handwriting on the original label, we guess that the voucher at LD was personally checked by Freyn in April 1902. Hence, the specimen LD-1667358 is selected here as lectotype. The voucher B-100278715 must be considered as isolectotype. Further investigation is needed to verify if the var. verrucifera is synonym the nominal variety.

Baum (1966: 33) considered the name of this variety as a nomen illegitimum, on the basis of the occurrence of galls on the exsiccatum. Baum's nomenclatural interpretation is not correct, and the name T. karakalensis var. verrucifera is legitimate according to the ICN (McNeill et al. 2012).

\section{Acknowledgements}

We would like to thank Karel Sutorý (BRNM) and Patrik Frödén (LD) for their valuable comments about Freyn and Sintenis's collections. The curators and staff of all herbaria consulted or visited: Hekan Wittzell (LD), Otakar Š́da (PR), Ernst Vitek (W), Jan Štěpánek (PRC, currently at PRA), Nicholas Foumeau (G), Laurent Gautier (G), James Solomon (MO), Robert Vogt (B) and Myriam Gaudeul (P). The FPU programme ( $\mathrm{M}^{\mathrm{o}}$ de Educación, Spain), I+D+i project CGL2008-05056 ( $\mathrm{M}^{\mathrm{o}}$ de Educación y Ciencia, Spain) and complementary supporting funds ACIE10-01, ACIE11-05 and ACIE13-08 (University of Alicante, Spain) made this research possible.

\section{References}

Baum, B. (1966) Monographic Revision of the genus Tamarix. Final research report for the USDA. Department of Botany, Hebrew University, Jerusalem, 193 pp.

Freyn, J. (1903) Plantae ex Asia Media. Bulletin de l'Herbier Boissier sér. 2, 3: 1058-1068.

McNeill, J., Barrie, F.R., Buck, W.R., Demoulin, V., Greuter, D.L., Hawksworth, D.L., Herendeen, P.S., Knapp, S., Marhold, K., Prado, J., Proud'Homme van Reine, W.F., Smith, J.F. \& Wiersema, J.H. (eds.) (2012) International Code of Nomenclature for algae, fungi and plants (Melbourne Code): Adopted by the Eichteenth International Botanical Congress, Melbourne, Australia, July 2011. Regnum Vegetabile 154: 1-274.

Samadi, N., Seyed, M. \& Akhani, H. (2013) Meiotic behaviour, karyotype analyses and pollen viability in species of Tamarix (Tamaricaceae). Willdenowia 43: 195-203. http://dx.doi.org/10.3372/wi.43.43121

Thiers, B. (2014) continuously updated. Index Herbariorum: A global directory of public herbaria and associated staff. New York Botanical Garden's Virtual Herbarium. Available from: http://sweetgum.nybg.org/ih. (Accessed: 7 March 2014). 